\title{
HUBUNGAN ANTARA KEPEMIMPINAN TRANSFORMASIONAL DAN IKLIM ORGANISASI DENGAN PRODUKTIVITAS KERJA GURU
}

\author{
Any Lestari ${ }^{1}$, Nandang Hidayat ${ }^{2}$, Karantiano Sadasa Putra ${ }^{2}$ \\ ${ }^{1}$ Guru SDN Sukadamai 2, Bogor, Jawa Barat \\ ${ }^{2}$ Program Pascasarjana Universitas Pakuan, \\ Email: pasca@unpak.ac.id
}

\begin{abstract}
This study outlines the relationship between transformational leadership and organizational climate with the productivity on Officcial Goverment Elementary School Teachers in Tanah Sareal Bogor in 2017. The research applies survey method with the Correlation approach. The population in this study was 256 teachers with the total sample of 157 teachers determined by proportionale random sampling. Data analysis techniques used descriptive statistical analysis techniques and inferential statistics. Inferential statistics are used to test hypotheses using simple regression and correlation analysis techniques and multiple regression and correlation analysis. Based on the research result, it is concluded that 1) there is a very significant positive relationship between transformational leadership with teacher work productivity, 2) there is a very significant positive relationship between organizational climate 3) there is a positive relationship Significant between transformational leadership and organizational climate with teacher work productivity Therefore, it can be concluded that teacher work productivity can be improved through transformational leadership and organizational climate either individually or collectively.
\end{abstract}

Keywords: Transformational Leadership, Organizational Climate, Productivity

\begin{abstract}
ABSTRAK
Penelitian ini bertujuan menentukan hubungan antara kepemimpinan transformasional dan Iklim organisasi dengan produktivitas guru PNS SD Negeri se-Kecamatan Tanah Sareal Kota Bogor pada tahun 2017. Metode penelitian menggunakan metode survey dengan pendekatan korelasional. Populasi penelitian berjumlah 256 guru PNS dengan jumlah sampel sebanyak 157 guru PNS yang ditentukan secara proporsional random sampling. Teknik analisis data menggunakan teknik analisis statistik deskriptif dan statistik inferensial.Penelitian ini menemukan 1) terdapat hub Terdapat hubungan positif dan sangat signifikan antara kepemimpinan transformasional dengan produktivitas kerja 2) Terdapat hubungan positif dan sangat signifikan antara variabel iklim organisasi dengan variabel produktivitas kerja guru 3) Terdapat hubungan positif dan sangat signifikan antara Kepemimpinan transformasional dan variabel iklim organisasi secara bersama-sama dengan variabel produktivitas kerja
\end{abstract}

Kata kunci: Produktivitas Guru , Kepemimpinan Transformasional, dan Iklim Organisasi 


\section{PENDAHULUAN}

Pendidikan berperan untuk membentuk manusia berkualitas yang menjadi ujung tombak kemajuan suatu bangsa. Pendidikan merupakan suatu proses transformasi nilai-nilai budaya sebagai kegiatan pewarisan budaya dari satu generasi ke generasi yang lain. Nilainilai kebudayaan tersebut mengalami proses transformasi dari generasi terdahulu sampai pada generasi sekarang dan yang akan datang. Pendidikan diselenggarakan sebagai suatu proses pembudayaan, dan pemberdayaan peserta didik yang berlangsung sepanjang hayat. Di mana dalam proses tersebut harus ada pendidik yang memberi contoh sebagai keteladanan dan mampu membangun kemajuan serta kreativitas peserta didik.

Guru sebagai tenaga profesional harus memiliki sifat kemandirian dalam seluruh kegiatan pembelajaran melalui jalur pendidikan baik dalam di sekolah maupun luar sekolah, guru memegang peranan yang penting sebagai fasilitator. Guru merupakan sumber daya manusia yang mampu mendayagunakan faktor-faktor lain sehingga tercipta suatu proses pembelajaran yang bermutu dan menjadi faktor utama yang menentukan mutu pendidikan. Guru harus memahami dan menghayati peserta didik yang dibimbingnya.

Perkembangan ilmu dan teknologi memberi dampak terhadap masyarakat Indonesia yang mempengaruhi gambaran lulusan suatu sekolah. Dalam proses pembelajaran guru harus memiliki kemampuan untuk mencapai harapan yang dicita-citakan. Untuk memiliki kemampuan tersebut guru perlu membina diri karena fungsi guru adalah membina dan mengembangkan kemampuan peserta didik secara profesional dalam proses pembelajaran. Namun kenyataan di lapangan guru belum melaksanakan tugas dengan baik sesuai harapan karena kemampuan guru belum menunjang pelaksanaan tugas. Guru dituntut dapat bekerja secara teratur, konsisten, serta kreatif dalam menjalankan tugasnya. Kemantapan dalam bekerja seharusnya merupakan karakteristik pribadinya, sehingga cara kerja guru dihayati oleh peserta didik, guru harus mempunyai kemampuan melaksanakan tugas dan tanggung jawabnya dengan baik.

\section{Produktivitas Kerja Guru}

Byars (2007:346) mengemukakan bahwa produktivitas didefinisikan sebagai unit keluaran per karyawan per jam. Produktivitas adalah hasil dari tiga komponen besar yang terpisah yaitu efisiensi teknologi, efisiensi tenaga kerja, hemat dana dan manajemen yang efektif untuk menghasilkan produksi lebih, dengan jumlah sumber daya yang sama. Dalam artikel yang ditulis Freeman (2008: p. 5) mendefinisikan produktivitas adalah rasio ukuran volume output ke volume penggunaan input yang digunakan. Adapun Produktivitas kerja guru dapat diartikan sebagai hasil kerja berdasar kemampuan profesional yang harus dimiliki.

Powers (2016:2) mengemukakan bahwa produktivitas tenaga kerja adalah ukuran statistik yang berkaitan dengan keluaran suatu industri jasa dengan kualitas tenaga kerja untuk menghasilkan layanan tertentu. Menurut Gibson (2012: 248) produktivitas kerja adalah satu tim yang merupakan cara untuk meningkatkan produktivitas organisasi. Pengertian tersebut menunjukkan bahwa produktivitas dapat ditingkatkan bila didalam organisasi dibentuk satu tim yang baik dalam melaksanakan pekerjaan.

Sekolah sebagai lembaga pendidikan akan menjadi maju jika memiliki tim kerja yang memiliki produktivitas tinggi. Haoubi (2016:2) berpendapat bahwa produktivitas dipengaruhi oleh kepuasan karyawan, ada hubungan sebab-akibat antara kepuasan dan produktivitas. Sekolah berusaha meningkatkan produktivitas guru dengan cara meningkatkan kepuasan kerja dan mengurangi stres kerja terhadap guru dan karyawannya dalam melaksanakan tugas. Stropkovă (2014:108) mengukur produktivitas secara umum output dan input adalah faktor inti pertumbuhan ekonomi, untuk memastikan sebuah keunggulan strategis.

Berdasarkan kajian teori-teori tersebut dapat disintesis bahwa produktivitas kerja guru adalah perbandingan hasil kerja yang dicapai guru dalam melaksanakan tugas di lingkungan kerjanya untuk menghasilkan karya (output) yang kreatif dan bermanfaat dengan menggunakan sumber daya (input) yang dihubungkan dengan waktu yang digunakan secara efisien sehingga 
muncul keinginan untuk memperbaiki cara mengajar lebih efektif untuk mencapai tujuan pendidikan.

\section{Kepemimpinan Transformasional}

Bass dan Riggio (2006: 6) menjelaskan kepemimpinan transformasional merangsang dan menginspirasi bawahannya untuk mencapai hasil yang optimal dalam rangka mengembangkan kemampuan memimpin. Menurut Rue dan Byars (2007: 245) kepemimpinan transformasional adalah kepemimpinan yang melibatkan karyawan untuk berkomitmen dalam organisasi, hubungan pimpinan dan karyawan saling mendukung yang ditandai dengan karisma pimpinan, inspirasi pimpinan terhadap karyawan, pemahaman pimpinan terhadap masing-masing karyawan, dan bimbingan intelektual oleh pimpinan terhadap karyawan. Perubahan kepemimpinan terhadap karyawan bukan hanya pada situasi tetapi juga pengikutnya.

Colcuit (2009: 490) kepemimpinan transformasional adalah kepemimpinan yang selalu melibatkan seluruh anggota sepakat untuk mewujudkan visi bersama yang bermakna untuk mengembangkan potensi yang dimiliki anggotanya dalam menghadapi permasalahan dari perspektif baru. Hellriegel dan Slocum (2008: 329) Kepemimpinan transformasional adalah pemimpin yang mengantisipasi tren masa depan, menginspirasi pengikutnya untuk memahami dan membangun organisasi. Adapun Luthans (2011: 430) mengemukakan bahwa kepemimpinan transformasional merupakan kepemimpinan yang mampu mengubah situasi menjadi lebih baik, menjadi figur teladan, menciptakan visi yang ideal serta mampu menginspirasi orang lain untuk berperilaku yang bermoral dan beretika.

Gibson (2012: 314) menjelaskan bahwa kepemimpinan itu melibatkan pengaruh dan semua hubungan interpersonal yang melibatkan kepemimpinan. Adapun Robbins dan Judge (2013: 417) menjelaskan bahwa kepemimpinan transformasional adalah pimpinan yang menginspirasi para pengikutnya untuk memyampaikan kepentingan pribadi mereka dan memiliki kemampuan mempengaruhi yang luar biasa. Ahmad (2014: 14) bahwa kepemimpinan transformasional adalah perilaku pemimpin yang ditandai oleh pengaruh ideal kepada pengikutnya, stimulasi intelektual, dan motivasi inspirasional agar tujuan organisasi tercapai sesuai dengan harapan. Dalam jurnalnya Middleton, Harvey, dan Esaki (2015:155) mengemukakan kepemimpinan transformasional berkaitan dengan pengembangan potensi dari individu dan memotivasi bawahan terhadap kebaikan yang lebih besar dibandingkan kepentingan diri mereka sendiri berdasarkan kerangka nilai yang dianut.

Dari beberapa kajian teori yang dipaparkan dapat disintesis bahwa kepemimpinan transformasional kepala sekolah adalah gaya kepemimpinan kepala sekolah yang berupaya untuk mempengaruhi bawahannya, menjadikan dirinya sebagai model yang bertanggung jawab, mentransfer ilmu kepada bawahan, memotivasi dan menginspirasi bawahannya, untuk menjalankan tugas dan kewajiban dengan baik menuju peningkatan sekolah ke arah yang lebih berkualitas.

\section{Iklim Organisasi}

Schermerhorn (2012: 9) Iklim organisasi adalah persepsi bersama anggota suatu organisasi mengenai kebijakan dan praktek manajemen. Iklim organisasi dipengaruhi oleh lingkungan sosial yaitu hubungan pimpinan dengan bawahan serta hubungan antar anggota, dan sistem manajemen yaitu tentang kebijakan dan praktek manajemen dalam organisasi. Mullins (2005: 899-900) menjelaskan bahwa iklim organisasi adalah kualitas yang relatif tetap dari lingkungan internal organisasi yang dialami oleh anggota yang mempengaruhi perilakunya, dan dijelaskan dalam seperangkat nilai-nilai pada karakteristik organisasi yang mempengaruhi cara kerjanya. Iklim organisasi menurut Bateman dan Snell (2015:71-72) adalah pola sikap dan tingkah laku yang membentuk seseorang berpengalaman dalam organisasi. Iklim organisasi dipengaruhi oleh sistem manajemen yang menentukan standar operasional kerja, peran anggota organisasi yang jelas, adanya penghargaan atas prestasi kerjanya. Selain itu juga dipengaruhi oleh hubungan pimpinan dan bawahan serta hubungan antar anggota. Hal ini sependapat dengan Noordin (2010: 1) iklim 
organisasi berdampak pada kinerja organisasi dan mempengaruhi motivasi pekerja. Iklim organisasi yang positif merupakan katalisator yang mendorong upaya dan komitmen utuk bertindak.

Schneider (2013: 362) dalam jurnalnya berpendapat iklim organisasi adalah sudut pandang yang dianut dan makna yang dilekatkan pada kebijakan, praktik, dan prosedur yang membentuk pengalaman, serta perilaku yang didukung dan diharapkan. Sejalan dengan pendapat Balausteguigitia (2007: 5) iklim organisasi sebagai interpretasi karyawan terhadap lingkungan kerja. Dalam jurnal Saungweme dan Gwandure (2011: 145) iklim organisasi digambarkan sebagai set karakteristik yang membuat pekerja dalam organisasi itu berbeda dari organisasi yang lain, mampu bertahan dalam waktu lama dan berpengaruh pada perilaku anggotanya. Dimensi yang mempengaruhi iklim organisasi adalah lingkungan sosial menenai hubungan interpersonal dan sistem manajemen yaitu manajemen konflik, sistem penghargaan atas kinerja.

Dari beberapa definisi di atas dapat disintesis bahwa iklim organisasi adalah persepsi bersama anggota organisasi tentang lingkungan tempat bekerja yang meliputi suasana internal organisasi, praktek manajemen dan kebijakan yang mempengaruhi perilaku guru dalam melaksanakan tugasnya.

\section{METODE PENELITIAN}

Penelitian ini dilaksanakan pada SD Negeri se- Kecamatan Tanah Sareal Kota Bogor Propinsi Jawa Barat yang berjumlah 31 Sekolah Dasar Negeri. Kegiatan penelitian ini dilakukan mulai bulan Januari sampai Oktober 2017. Metode dalam penelitian adalah metode survei dan pendekatan studi korelasional.

Populasi dalam penelitian ini adalah guru PNS yang sudah bersertifikat pendidik Sekolah Dasar Negeri se- Kecamatan Tanah Sareal Kota Bogor dengan jumlah populasi 256 orang guru yang berada di 31 Sekolah Dasar Negeri, dengan jumlah sampel sebanyak 157 orang

\section{HASIL PENELITIAN}

\section{Pengujian Persyaratan Analisis}

1. Uji Normalitas

a. Uji normalitas pada galat baku Data Produktivitas Kerja Guru (Y) atas Kepemimpinan Transformasional $\left(\mathrm{X}_{1}\right)$

Berdasarkan hasil perhitungan uji normalitas galat baku taksiran $\left(\mathrm{Y}-\hat{\mathrm{Y}}_{1}\right)$ variabel Produktivitas Kerja (Y) atas Kepemimpinan Transformasional (X1) diperoleh nilai Lhitung sebesar 0,040 yang lebih kecil dari nilai Ltabel sebesar 0,071, pada taraf signifikansi 0,05, maka dengan demikian dapat disimpulkan bahwa galat baku taksiran Produktivitas Kerja atas variabel Kepemimpinan Transformasional berasal dari populasi yang berdistribusi normal

\section{b. Uji normalitas galat baku Data Produktivitas Kerja Guru (Y) atas Iklim Organisasi $\left(\mathbf{X}_{2}\right)$}

Perhitungan uji normalitas galat baku taksiran $\left(\mathrm{Y}-\hat{\mathrm{Y}}_{2}\right)$ variabel Produktivitas Kerja (Y) atas Iklim Organisasi $\left(\mathrm{X}_{2}\right)$ menghasilkan nilai Lhitung sebesar 0,069. Karena nilai Lhitung < Ltabel, pada taraf signifikansi 0,05, maka dapat disimpulkan bahwa galat baku taksiran Produktivitas Kerja terhadap atas iklim organisasi juga berasal dari populasi berdistribusi normal,

\section{Uji Homogenitas}

\section{a. Uji Homogenitas Produktivitas Kerja Guru atas Kepemimpinan Transformasional $\left(\mathbf{X}_{1}\right)$ \\ Dari hasil perhitungan uji homogenitas variabel Produktivitas Kerja atas variabel} Kepemimpinan Transformasional diperoleh nilai $\chi 2$ hitung sebesar 46,94 sedangkan $\chi$ 2tabel pada taraf signifikansi $\alpha=0,05$ adalah 73,31. Dengan demikian dapat disimpulkan bahwa kelompok data 
Produktivitas Kerja atas variabel Kepemimpinan Transformasional berasal dari populasi yang homogen.

\section{b. Uji Homogenitas Produktivitas Kerja Guru (Y) atas Iklim Organisasi $\left(\mathbf{X}_{2}\right)$}

Perhitungan uji homogenitas variabel Produktivitas Kerja (Y) atas variabel Iklim

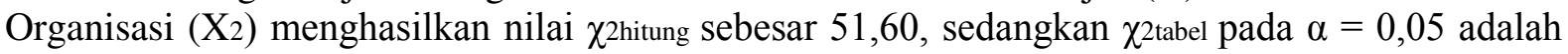

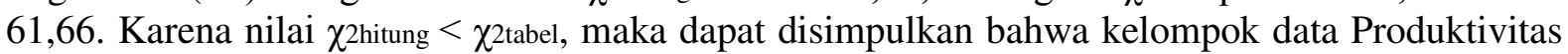
Kerja atas variabel Iklim Organisasi berasal dari populasi homogen.

\section{Pengujian Hipotesis}

\section{Hubungan antara variabel Kepemimpinan Transformasional dengan Produktivitas Kerja Guru}

Berdasarkan uji dengan menggunakan analisis varians (ANAVA) diperoleh nilai koefisien regresi b sebesar 0,35 dan nilai konstanta a sebesar 89,08. Maka persamaan regresi antara variabel kepemimpinan transformasional $\left(\mathrm{X}_{1}\right)$ dan produktivitas $(\mathrm{Y})$ adalah $\mathrm{Y}=89,08+0,35 \mathrm{X}_{1}$. Adapun untuk mengetahui apakah persamaan regresi dapat digunakan untuk menarik kesimpulan signifikan atau tidak, maka digunakan analisis varians (uji-F). Berdasarkan hasil analisis regresi linier sederhana antara Kepemimpinan Transformasional dengan Produktivitas Kerja menghasilkan diketahui bahwa persamaan regresi $\hat{Y}=89,08+0,35 \mathrm{X}_{1}$ dapat digunakan untuk mengambil kesimpulan mengenai hubungan kepemipinan Transformasioanl dengan produktivitas. Uji signifikansi dan linieritas terhadap persamaan regresi dilakukan dengan menggunakan uji $\mathrm{F}$ dengan ketentuan, hubungan dinyatakan signifikan apabila nilai Fhitung = 33,93 lebih besar dari nilai Ftabel $=3,90$ pada taraf signifikansi $\alpha=0,05$. Hal ini berarti Fhitung > Ftabel atau 33,93 > 3,90

\section{Hubungan variabel Iklim Organisasi dengan Produktivitas Kerja Guru}

Berdasarkan hasil uji signifikansi, ditemukan bahwa harga Fhitung sebesar 43,43 sedangkan Ftabel dengan $\mathrm{dk}$ pembilang $=1 \mathrm{dan} \mathrm{dk}$ penyebut $=155$ pada taraf signifikansi $\alpha=0,01$ adalah 6,80 dan pada taraf signifikansi $\alpha=0,05$ adalah 3,90. Dengan demikian harga Fhitung $>$ Ftabel, hal ini menunjukkan bahwa $\hat{\mathrm{Y}}=49,06+0,63 \mathrm{X}_{2}$ dapat dipergunakan sebagai acuan untuk memprediksi Produktivitas Kerja melalui Iklim Organisasi. Hasil perhitungan korelasi sederhana menunjukkan kekuatan hubungan antara variabel Iklim Organisasi dengan Produktivitas Kerja ditunjukkan oleh koefisien korelasi ry.2 $=0,468$ dengan koefisien determinasi r2y.2 =0,219. Hal ini berarti bahwa Iklim Organisasi memberi kontribusi sebesar 21,9\% terhadap Produktivitas Kerja, sedangkan 78,1\% Produktivitas Kerja dipengaruhi oleh faktor lain.

Untuk mengetahui korelasi $\mathrm{r}_{\mathrm{x} 2 \mathrm{y}}$ dihasilkan signifikan atau tidak dilakukan dengan uji-t. Berdasarkan hasil analisis diperoleh thitung $=6,59$ sedangkan tabel $=1,97$ pada taraf $\alpha=0,05$ dengan $\mathrm{dk}=\mathrm{n}-2=155$. Adapun pada taraf signifikansi $\alpha=0,01$ diperoleh tabe $=2,61$. Karena thitung $>$ ttabel, maka koefisien korelasi antara Iklim Organisasi dan Produktivitas Kerja sangat signifikan.

\section{Hubungan antara Kepemimpinan Transformasional $\left(X_{1}\right)$ dan Iklim Organisasi Sekolah $\left(\mathrm{X}_{2}\right)$ secara Bersama-sama dengan Produktivitas Kerja Guru (Y)}

\section{a. Uji Regresi Ganda}

Berdasarkan hasil analisis regresi linier ganda antara kepemimpinan transformasional dan iklim organisasi secara bersama-sama terhadap produktivitas kerja menghasilkan persamaan $\hat{\mathrm{Y}}=32,09+0,25 \mathrm{X} 1+0,50 \mathrm{X} 2$. Hal ini menunjukkan bahwa nilai koefisien regresi b1 yang diperoleh yaitu 0,25 dan nilai koefisien b2 yaitu 0,50 dengan nilai konstanta sebesar 32,09. 
Berdasarkan hasil uji signifikansi di atas, ditemukan bahwa persamaam regresi $\hat{\mathrm{Y}}=$ $32,09+0,25 \mathrm{X} 1+0,50 \mathrm{X} 2$ dapat digunakan untuk menjelaskan dan mengambil kesimpulan mengenai hubungan antara kepemimpinan transformasional dan iklim organisasi secara bersama-sama dengan produktivitas karena nilai Fhitung sebesar 33,84 sedangkan Ftabel dengan $\mathrm{dk}$ pembilang $=2 \mathrm{dan} \mathrm{dk}$ penyebut $=155$ pada taraf signifikansi $\alpha=0,01$ adalah 6,80 dan taraf signifikansi $\alpha=0,05$ adalah 3,90. Dengan 78 demikian harga Fhitung $>$ Ftabel, hal ini menunjukkan persamaan $\hat{Y}=32,09+0,25 \mathrm{X} 1+0,50 \mathrm{X} 2$ dapat dipergunakan sebagai acuan untuk memprediksi Produktivitas melalui Kepemimpinan Transformasional dan Iklim Organisasi.

\section{b. Uji Korelasi Ganda}

Kekuatan hubungan antara variabel Kepemimpinan Transformasional dan Iklim Organisasi dengan variabel Produktivitas ditunjukkan oleh koefisien korelasi ry. $12=0,553$ dengan koefisien determinasi r2y.12 = 0,305. Hal ini berarti bahwa Kepemimpinan Transformasional dan Iklim Organisasi secara bersama-sama memberi kontribusi sebesar 30,5\% terhadap Produktivitas, sedangkan 69,5\% Produktivitas Kerja dipengaruhi oleh faktor lain. Untuk menguji signifikansi hubungan positif antara Kepemimpinan Transformasional dan Iklim Organisasi dengan Produktivitas Kerja diperlukan uji signifikansi koefisien korelasi ganda, yaitu uji F. Jika Fhitung > Ftabel, maka koefisien korelasi ganda dinyatakan signifikan.

Berdasarkan hasil perhitungan diperoleh Fhitung $=33,83$, sedangkan Ftabel $(0,05)(2,155)=3,90$. Karena Fhitung $>$ Ftabel, maka koefisien korelasi antara Kepemimpinan Transformasional dan Iklim Organisasi dengan Produktivitas Kerja adalah sangat signifikan. Dengan demikian dapat disimpulkan bahwa hipotesis nol (H0) ditolak dan hipotesis alternatif (H1) diterima.

\section{Uji Korelasi Parsial}

Berdasarkan hasil perhitungan, diperoleh nilai korelasi parsial antara Kepemimpinan Transformasional dengan Produktivitas, jika Iklim Organisasi dikendalikan sebesar ry1.2 = 0,333.Untuk menguji signifikansi koefisien korelasi parsial dengan variabel Iklim Organisasi sebagai kontrol didapat nilai thitung sebesar 4,38 sedangkan nilai ttabel $=2,61$. Nilai thitung yang lebih besar dari ttabel menunjukkan bahwa hubungan antara Kepemimpinan Transformasional dengan Produktivitas, dimana nilai Iklim Organisasi dikontrol adalah signifikan.

Hal ini menunujukkan bahwa terjadi hubungan tidak signifikan dan sangat lemah antara kepemimpinan transformasional dengan Produktivitas dimana variabel Iklim Organisasi dikendalikan (dikontrol). Arah hubungan positif karena nilai $\mathrm{r}$ positif. Hal ini menunjukkan bahwa terjadi hubungan tidak signifikan dan sangat lemah antara Iklim Organisasi dengan Produktivitas dimana variabel kepemimpinan transformasional dikendalikan (dikontrol). Arah hubungan positif karena nilai $r$ positif. Sedangkan hubungan tersebut apabila dikontrol oleh kepemimpinan transformasional maka hubungan Iklim Organisasi dengan Produktivitas Kerja terdapat hubungan yang signifikan dengan kekuatan rendah, dengan nilai 0,391, arah hubungan positif. Dari kedua hubungan tersebut dengan arah positif artinya bahwa semakin tinggi Iklim Organisasi, maka semakin meningkatkan Produktivitas Kerja. 


\section{PEMBAHASAN}

\section{Hubungan Antara Kepemimpinan Transformasional Dengan Produktivitas Kerja Guru}

Hasil penelitian menunjukkan bahwa terdapat hubungan positif antara Kepemimpinan Transformasional dengan Produktivitas Kerja guru. Hal ini ditunjukkan oleh koefisien korelasi (ry.1) sebesar 0,424 yang dinyatakan sangat signifikan. Kontribusi Kepemimpinan Transformasional Produktivitas Kerja sebesar 18,0\% yang dinyatakan dengan nilai koefisien determinasi (r2y.1) sebesar 0,180. Koefisien korelasi parsial Kepemimpinan Transformasional (dengan variabel Iklim

Organisasi dikendalikan) adalah sebesar 0,333 yang dinyatakan sangat signifikan. Pola hubungan antara variabel kepemimpinan transformasional (X1) dengan produktivitas (Y) dinyatakan dengan persamaan regresi linier sederhana $\hat{Y}=89,08+0,35 \mathrm{X} 1$, diprediksi bahwa setiap kenaikan satu skor Kepemimpinan Transformasional akan menyebabkan kenaikan 0,35 skor Produktivitas Kerja pada konstanta 89,08. Hasil penelitian ini menyimpulkan bahwa Kepemimpinan Transformasional yang dimiliki memberikan kontribusi positif yang berpengaruh nyata terhadap Produktivitas Kerja.

Penelitian lain yang dilakukan oleh Asep (2016), menyatakan bahwa Analisis regresi linear ganda antara kepemimpinan transformasional kepala sekolah dan iklim organisasi sekolah secara bersama-sama dengan produktivitas kerja guru ditampilkan dalam bentuk persamaan regresi sebagai berikut: $\hat{\mathrm{Y}}=75,03+0,386$. X1 $+0,187 \mathrm{X} 2$, dengan arah koefisien regresi a1 sebesar 0,386, a2 sebesar 0,187 dan konstanta a0 sebesar 75,03. Hasil perhitungan uji keberartian persamaan regresi linear ganda diperoleh Fhitung $=5,095$ yang lebih besar dari Ftabel $=3,060$

Dengan demikian temuan fakta dan data dalam analisis penelitian ini semakin mendukung temuan-temuan terdahulu mengenai adanya hubungan yang kuat antara Kepemimpinan Transformasional terhadap Produktivitas Kerja baik secara langsung ataupun tidak langsung.

Berdasarkan hasil penelitian dan pembahasan di atas, maka dapat dilihat hubungan positif antara kepemimpinan transformasional kepala sekolah dengan produktivitas kerja guru. Produktivitas kerja guru akan tinggi jika dipengaruhi oleh gaya kepemimpinan kepala sekolah yang mentransfer ilmu dan menjadikan dirinya sebagai model yang bertangguga jawab, mampu menginspirasi guru dalam memingkatkan produktivitas kerja. Hal ini diindikasikan bahwa salah satu upaya untuk meningkatkan roduktivitas kerja guru adalah dengan meningkatkan atau mengembangkan Kepemimpinan Transformasionalnya.

\section{Hubungan antara Iklim Organisasi dengan Produktivitas Kerja Guru}

Hasil penelitian menunjukkan bahwa terdapat hubungan positif antara Iklim Organisasi dengan Produktivitas Kerja. Hal ini ditunjukkan oleh koefisien korelasi (ry.2) sebesar 0,468 yang dinyatakan signifikan. Kontribusi Iklim Organisasi terhadap Produktivitas Kerja sebesar 21,9\% yang dinyatakan dengan nilai koefisien determinasi (r2y.2) sebesar 0,219. Koefisien korelasi parsial Iklim Organisasi (dengan variabel Kepemimpinan Transformasional dikendalikan) adalah sebesar 0,391 yang dinyatakan signifikan pada taraf $\alpha=0,05$.

Pola hubungan antara variabel terhadap dengan variabel Produktivitas Kerja dinyatakan dengan persamaan regresi linier sederhana $\hat{Y}=49,06+0,63 \mathrm{X} 2$, diprediksi bahwa setiap kenaikan satu skor Iklim Organisasi akan menyebabkan kenaikan 0,63 skor Produktivitas 
Kerja pada konstanta 49,06. Terdapatnya hubungan yang positif antara Iklim Organisasi dengan Produktivitas Kerja menunjukkan bahwa peran Iklim Organisasi sangat membantu tercapainya Produktivitas Kerja.

Hal ini sesuai dengan hasil penelitian sebelumnya yang dilakukan Rajeesh Viswanathan tahun 2015 terhadap karyawan IT dan ITES dari Chennal dan Bangalore, yang berjudul "A Study on Impact of organizational Climate on Productivity in it \& Ites Sector" . Data yang diuji melalui alpha cronbach dan nilai realibilitasnya adalah 0,878 melalui korelasi dan regresi. Telah ditemukan hubungan antara iklim organisasi dan produktivitas, ditemukan adanya hubungan positif dengan nilai signifikan antara dua analisis reliabilitas variabel. Alpha Cronbach dengan jumlah item 55 adalah 0,878 menunjukkan hubungan korelasi antara iklim organisasi dan produktivitas kerja.

Selain itu juga penelitian yang dilakukan oleh Any Sofyani tahun 2016 yang berjudul : "Hubungan antar Kepemimpinan Transformasional Kepala Sekolah dan Iklim Organisasi dengan Produktivitas kerja guru SMA Negeri di Wilayah Timur Kabupaten Kerawang “ Terdapat hubungan positif yang signifikan antara iklim organisasi (X2) dengan produktivitas kerja guru $(Y)$ dengan koefisien korelasi ry2 $=0,234$ dan persamaan regresi $\hat{Y}=111,8+0,233$ $\mathrm{X} 1$. Terdapat hubungan positif yang signifikan antara kepemimpinan produktivitas kerja guru (Y) dengan koefisien korelasi ry.1.2 $=0$, transformasional (X1) dan iklim organisasi (X2) secara bersama-sama dengan 317 dan persamaan regresi $\hat{Y}=91,15+0,218 \mathrm{X} 1+0,170 \mathrm{X} 2$

Berdasarkan temuan fakta dan data dalam analisis penelitian ini hasil kerja guru meningkat maka diperlukan lingkungan fisik, sarana prasarana, sistem manajerial dan hubungan antar personal akan berpengaruh pada guru dalam melaksanakan tugasnya sehingga dapat menghasilkan produk dan hasil capaian kerja berkualitas. Berdasarkan hasil penelitian dan pembahasan di atas, maka temuan dalam penelitian ini menyatakan bahwa terdapat hubungan positif yang sangat signifikan antara iklim organisasi dengan produktivitas kerja guru sudah didukung oleh penelitian sebelumnya dan didukung teori iklim organisasi. Maka dapat dijelaskan bahwa untuk meningkatkan produktivitas kerja guru adalah dengan meningkatkan iklim organisasi yang mendukung.

\section{Hubungan antara Kepemimpinan Transformasional dan Iklim Organisasi Sekolah secara Bersama-sama dengan Produktivitas Kerja Guru.}

Hasil penelitian menunjukkan bahwa terdapat hubungan positif antara Kepemimpinan Transformasional dan Iklim Organisasi secara bersama-sama dengan Produktivitas Kerja. Hal ini ditunjukkan oleh koefisien korelasi (ry.12) sebesar 0,553 yang dinyatakan sangat signifikan setelah diuji dengan uji F. Kontribusi Kepemimpinan Transformasional dan Iklim Organisasi secara bersama-sama terhadap Produktivitas Kerja sebesar 30,5\% yang dinyatakan dengan nilai koefisien determinasi (r2y.12) sebesar 0,305.

Pola hubungan antara variabel Kepemimpinan Transformasional dan Iklim Organisasi secara bersama-sama dengan variabel Produktivitas Kerja ditunjukkan dengan persamaan regresi linier ganda $\hat{\mathrm{Y}}=32,09+0,25 \mathrm{X} 1+0,50 \mathrm{X} 2$ dengan koefisien regresi yang dinyatakan sangat signifikan. Hubungan tersebut merupakan hubungan

yang memiliki arti bahwa jika faktor variabel kepemimpinan kepala sekolah (X1) dan iklim organisasi (X2) ditingkatkan maka akan terjadi peningkatan variabel produktivitas kerja guru sebagai akibat dari tingkat hubungan variabel X1, X2 terhadap Y. Dari persamaan regresi tersebut menggambarkan perolehan $\mathrm{Y}$ bertambah sebesar 0,25 X1+0,50X2 yang artinya bahwa setiap peningkatan satu unit nilai kepemimpinan transformasional dan iklim organisasi akan diikuti oleh peningkatan produktivitas kerja guru sebesar 0,25 dan 0,50 unit untuk konstanta 32,09.

Nilai Fhitung diperoleh lebih besar dari Ftabel pada taraf signifikan si 0,05 dan 0,01, menunjukkan regresi hubungan antara kepemimpinan transformasional dan iklim organisasi 
secara bersama-sama dengan produktivitas kerja guru adalah sangat signifikan sehingga persamaan regresi ini dapat digunakan untuk memprediksi skor produktivitas bila skor kepemimpinan transformasional dan iklim organisasi dketahui.

Besaran Koefisien korelasi ganda ( ry.1.2 = 0,553) terlihat lebih besar pada saat variabel Kepemimpinan Transformasional dan iklim organisasi bersama-sama dengan produktivitas kerja guru dibandingkan pada saat kedua variabel bebas sendiri-sendiri. Hal ini berarti kekuatan hubungan terhadap produktivitas kerja guru. Akan lebih besar bila Kepemimpinan Transformasional dan iklim organisasi ditingkatkan secara bersama-sama. Kontribusi hubungan dapat diketahui dari hasil perhitungan koefisien determinasi yang merupakan kuadrat dari koefisien korelasi sederhana tersebut ditunjukkan dengan koefisien determinasi ( $\mathrm{r} 2$ y.1.2 = 0,305 hal ini berarti kepemimpinan transformasional dan iklim organisasi bersama-sama dengan produktivitas kerja guru memberi kontribusi sebesar 30,5\% dan sisanya $69,5 \%$ produktivitas kerja guru dipengaruhi oleh faktor lain. Hal ini menunjukkan bahwa terjadinya peningkatan produktivitas kerja guru merupakan hasil dari kepemimpinan transformasional dan iklim organisasi suatu sekolah. Semakin tinggi kepemimpinan transformasional yang dimiliki kepala sekolah dan iklim organisasi yang semakin baik akan meningkat pula produktivitas kerja guru.

Peran Kepemimpinan Transformasional bagi tenaga pendidik adalah mampu mengubah situasi menjadi lebih baik, menjadi figur teladan, menciptakan visi yang ideal serta mampu menginspirasi orang lain untuk berperilaku yang bermoral dan beretika. Ada beberapa karakter kepemimpinan transformasional yaitu: karisma, inspirasi, rangsangan intelektual, dan pertimbangan individu. Hal ini sesuai dengan hasil penelitian sebelumnya yang dilakukan R. F. Piccolo dan Jason A. Colquit (2006: p. 327), yaitu kepemiminan transformasional mempunyai efek yang mempengaruhi cita-cita pengikut/bawahan dan nilai-nilai kepemimpinan dapat meningkatkan komitmen untuk visi yang diinformasikan dengan baik dan menginspirasi pengikut untuk mengembangkan cara-cara baru untuk berpikir tentang permasalahan.

Berdasarkan hasil penelitian yang dikemukakan di atas, dapat disimpulkan bahwa terdapat hubungan positif yang sangat signifikan antara kepemimpinan transformasional dan Iklim Organisasi secara bersama-sama dengan produktivitas kerja guru.Variabel bebas yang mempunyai hubungan lebih kuat dan kontribusi lebih besar terhadap Produktivitas Kerja adalah iklim organisasi.

\section{SIMPULAN}

Berdasarkan analisis terhadap data hasil penelitian dapat disimpulkan terdapat hubungan positif sangat signifikan antara kepemimpinan transformasional dengan produktivitas kerja guru, antara iklim organisasi dengan produktivitas kerja guru, antara kepemimpinan transformasional dan iklim organisasi secara bersama-sama dengan produkrivitas kerja guru.

Berdasarkan hasil penelitian ini maka untuk meningkatkan produktivitas kerja guru dapat dilakukan dengan meningkatkan kepemimpinan transformasional dan perbaikan pada iklim organisasi. 


\section{DAFTAR PUSTAKA}

Bass M. Bernard, Ronal E. Riggio. 2006. Transformational Leadership.second edition. London: Lawrence Erlbaum associates, Publisher

Balkar Betül. 2015. The Relationships Between Organizational Climate, Innovative Behavior and Job Performance of Teachers. International Online Jurnal of Educational Sciences. Volume 7

Bateman/ Snell. 2015. Management Leading and Collaborating In Copetitive Word. New York.11th Edition: Mc Graw-Hill International Edition.

Bureš Vladimír, Andrea Stropková. 2014. Labour Productivity and Possibilities of its Extension by knowledge Management Aspects. Procedia-Social and Behavioral Sciences. Volume 109: 1088-1093.

Colquitt A. Jason, Jeffery A. Lepine. Michael J.Wesson. 2009. Organizational Behavior: Improving Performance in commitment in the workplace. United State: McGrraw-Hill Irwin

Hellriegel Don, John W Slocum. 2008. Organizational Behavior. 13th edition. USA: SouthWestern Cengage Learning

Freeman Rebecca. 2008. Labour Productivity Indicators Comparison of two OECD data base Productivity defferentials \& The Balassa-Samuelson Effect. Organization for economic go operation development

Luthans Fred. 2011. Organizational Behavior En Evidence-Based Approah. Twelth Edition, Americas, New York: McGraw-Hill Irwin

Gibson L. James , James H. Donnelly, John M. Ivancevich, Robert Konopaske. 2012. Organizations Behavior, Structure, Processes, Fourteenth Edition . Singapore: McgGraw- Hill International Edition

M. Birasnav, Rangnekar S \& Dalpati A. 2010, Transformational Leadership , interim Leadership, and employee human capital benefits: an empirical Study. Procedia Social an Behavioral Sciences. No.5 : 1017-1042.

Noordin Fauziah, Safiah Omar, Syakirarohan Sehan, Shukriah Idrus. 2010, Organizational Climate and Its Influence on Organizational Commitment: International Business \& Economics Research Journal.

Piccolo F. Ronald, Jason A.Colquitt. 2006. Transformational Leadership and Job Behaviors: The Mediating Role Of Core Job Characteristics. Academy of Management Journal

Powers G. Susan. 2016, Labor Productivity growth inelementary and secondary school. Monthly Labor Review.

Robbins P. Stephen, Tymothy A.Judge .2013. Organizational Behavior. Global Edition. New York: Pearson. 
Rue W. Leslie , Llyod L.Byars. 2007.Supervision. Key Link to Productivity. Amerika, New York : McGraw-Hill Irwin.

Saungweme Ruvarashe, Calvin Gwandure. 2011. Organzational Climate and Intent To leave among Recruitment Consultants in Johannesburg, South Africa, J Hum Ecol.

Scheneider Benjamin, Mark G Ehrhart \& William H. Macey. 2013. Organizational Climate and Culture. Annu.Rev.Psychol.

Schermerhon R. John, Osborn N, Richard, Bien-Uhl Mary, Hunt g. James. 2012. Organizational Behavior. International Student Version. Asia: John Wiley \& Sons ( Asia) Ptc. Ltd.

Sedarmayanti. 2001. Sumber Daya Manusia dan produktivitas kerja. Bandung: Mandar Maju.

Soltani Iraj, Mohammad Reza Pajoohi dan Abolghasem Ebrahimi. 2014. Investigating The Relationship Between Transformasional Leadership and Employees' Productivity In Shiraz Special Economic Zone. Journal of Novel Appled Science.

Viswanathan Rajeesh 2015. A study on The Impact of Organizational Cimate onProductivity in it \& Ites Sector. Indian Journal of applied research. 